\title{
1 Kings 12:1-24 and effects of hate speech in Nigeria
}

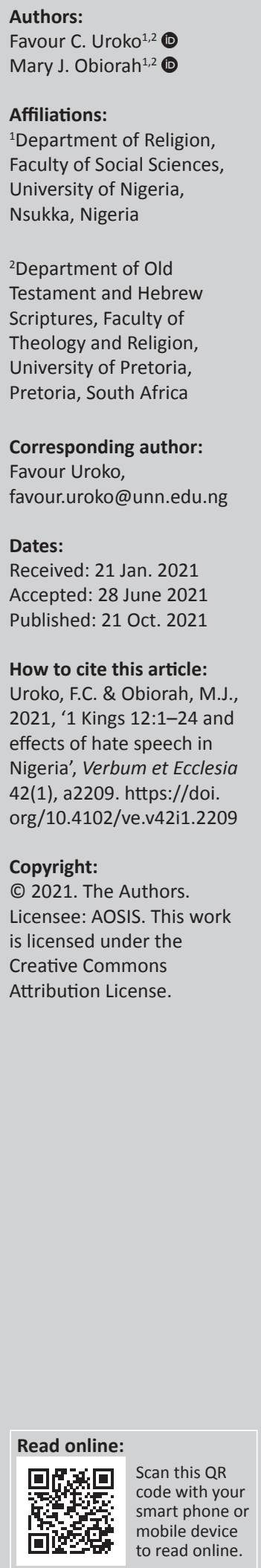

This article examines the effect of hate speech in Nigeria in the light of 1 Kings 12:1-24. Hate speech refers to any speech that subordinates, marginalises or harms members of a group. The analysis of the text unveils how Rehoboam's speech inhibits and exhibits hate, subordination and neglect of citizens he was ruling based on tribal difference. Rehoboam's father, Solomon, placed a heavy burden especially on the people of northern Israel. After Solomon's death, the people hoped for a review and possible annihilation of the biased policies by Rehoboam. Unfortunately, Rehoboam's response was full of hate. The people of Israel also responded with hate speech towards Rehoboam. Thus, the exchange of hate speech from the ruler to the ruled occurred. This led to a divided Israel, opened to attacks. This analysis affords an insight into the problem of hate speech in Nigeria. There is a general perception that a particular set of people are favoured by federal government in Nigeria. This had further intensified ethnic tension, ethno-religious disunity and calls for disintegration of Nigeria. The pericope (1 Ki 12:1-24) speaks anew about the problem of ever-increasing hate speech in Nigeria.

Intra/interdisciplinary implications: This research is based on the importance of hate speech in 1 Kings 12:1-24. Similar to what is obtainable amongst Nigerians, 1 Kings 12 reveals that harmful speech from the ruler and the ruled have far-reaching implications. It leads to the destruction of lives and property. Disciplines implicated include Old Testament and ethnicity and Communication Studies.

Keywords: Rehoboam scorpion; Solomon; 1 Kings 12; hate speech; scorpion.

\section{Introduction}

On 28 February 2018, Senator Aliyu Sabi Abdullahi sponsored the 'Hate Speech Bill'. The bill recommended a death sentence for any person found guilty of hate speech (Alechenu, Baiyewu \& Aluko 2018:1). According to the bill, hate speech is any speech that has the intent of denigrating, repressing, harassing and death of a person or group of persons on the basis of tribal affiliation, sex, religion or ethnic group. For instance, the hate speech expressed by Oba Akiolu of Lagos:

On Saturday, if anyone of you, I swear in the name of God, goes against my wish that Ambode will be the next governor of Lagos state, the person is going to die inside this water ... For the Igbos and others in Lagos, they should go where the Oba of Lagos heads to .... (Godwin 2015:1)

Or the hate speech expressed by the Northern Elders Forum 'We'll regard anyone who votes for PDP as enemy of North' (Edeh 2014:1), which is specifically directed against people of southern Nigeria. These speeches express hatred towards a group and it is derogatory and humiliating (Davidson et al. 2017:1). In Nigeria, hate speech, from observation, emanates from leaders and citizens and this has led to an increase in religious bigotry, tribal and ethnic suspicion (Cortese 2006:77) and overall underdevelopment of Nigeria. The failure of other approaches in curbing this sad development led to the need to approach this problem from Old Testament perspective using 1 Kings 12:1-24 as a light.

A perusal of the remote context of 1 Kings 12 reveals Solomon who is portrayed as complying with David's instructions (1 Ki 2:12-46a). An implicit critique of Solomon's reign appears even in the narrative concerning Solomon's administration of the land (1 Ki 4:1-20), which depicts the 12 administrative districts of Solomon's kingdom, each of which is obligated to support the king's court for a month. It is clear that the system is heavily weighted in favour of Solomon's own tribe of Judah, which is responsible for only one month of royal support each year in contrast to the 11 months for which the rest of the kingdom is responsible. This is particularly noteworthy in relation to the charges by the northern tribes of Solomon's harsh treatment (1 Ki 12) 
(Sweeney 2012:73). Rehoboam took over the government of a united Israel after the death of his father. He was 41 years of age when he ascended the throne (1 Ki 14:21) (Malamat 1963:8). The depressed and deprived northern inhabitants of Israel met Rehoboam and requested a removal of the economic and physical burden that Solomon had placed on them before his death. The response of Rehoboam to the cry of the northern Israelites was demeaning, abusive, tribalised and threatening. This hate speech being exchanged between Rehoboam and the Israelites led to a serious conflict and finally the collapse and captivity of both kingdoms by their enemies. The narrative of 1 Kings 12:1-24 will be used as the pericope for an understanding of the effects of hate speech in the context of Nigeria.

It is important to state that Politics, Economics, Psychology and Law, are foremost amongst the disciplines that have shaped the emerging field of hate speech studies. The Old Testament, however, is rarely mentioned in major research works on hate speech studies as if the field is 'disciplinary refugee' (Groody 2009:640). The accelerating reality of the harm in hate speech in Nigeria provides an opportunity to include the Old Testament (1 Ki 12:1-24) amongst the literature on hate speech. The narrative analysis was used to examine hate speech and its implications to the continued existence of Israel, appropriating it to Nigeria's environment. The narrative analysis as a method is mostly used for stories and personal testimony (Obiorah 2015).

Firstly, this research surveys 1 Kings 12:1-24. Secondly, it examines hate speech in Israel and its short- and long-term implications. Thirdly, the discussion shows hate speech and its relationship with hate actions. Fourthly, it engages hate speech in Nigeria's environment. Finally, the article applies the pericope of 1 Kings 12:1-24 to the Nigerian context.

\section{The context of 1 Kings 12}

Kings explores the history of monarchy in Israel beginning from the reign of Solomon. Hale and Thorson (2007:608) placed the date at 970 BC Kings closes with King Jehoiachin's release from prison by the Babylonian king Evil-Merobach who became king of Babylon around 560 BC, after which the book of Kings took its final form (Gotom 2006:407). In Kings, the Deuteronomist cites three sources by name and repeatedly refers the reader to them for further information: the Acts of Solomon, the Chronicles of the Kings of Judah and the Chronicles of the Kings of Israel (Walsh \& Begg 2018:160). These research documents have been lost. It is important to state that the theology of the 1 Kings is that the "exile and the devastation of Jerusalem and the Temple are to be explained in the light of the conduct of Kings and people' (Heater 1991:151). In this section, the framework that surrounds the events of 1 Kings 12 could be seen from two perspectives.

\section{Remote context}

David had been able to advise his son on how to govern, but Solomon did not see his son ascend to the throne because his son, Rehoboam, lacked the advice of a God-fearing father (Gotom 2006:431). Solomon began his rule in an excellent manner; however, he started some dealings that doomed his government. He had a contract with the corvée, which is characterised by unwise dealings and injustice (Parker 1992:84). In the ancient Near East, levies are used as a means of forced labour from subjects (corvée) by states. It was used to carry out work on all their large-scale public works (Houston 2018:30). This is seen in 1 Kings 9:15-28, which shows the violation of the laws of God (Torah). His regime exhibits tendencies that are characteristic of a tyrannical dictatorship, which is seen in the institution of slavery in the form of the slave labour (1 Ki 9:21) (Parker 1992:84). Solomon looked at the Egyptians for help, furthermore enslaving the freed Israelites. In the second corvée, labour was directed to the building of store cities for the safety of the horsemen and chariots of Solomon, fleet of ships and also for the erection of a house for the daughter of Pharaoh. Labour was not geared towards the building of the temple (Gray 1970:243-249). It was used so as to boost Solomon's military strength and safety. The desire for prestige was his aim (Montgomery 1950:210). In fact, 1 Kings 11:6 tells about this distance as follows: ' $[a]$ nd Solomon did what was evil in the sight of the LORD, and did not totally follow the LORD, as David his father had done'.

Forced labour was an institution accepted in Egypt and Mesopotamia but was foreign to Hebrew customs and traditions (McKenzie 1992:726). As known from 1 Kings 5:27, Solomon imposed forced labour on the entire Israel; furthermore, in order to administer the collection of revenues and the draft of forced labour, Solomon reorganised the kingdom into 12 districts (McKenzie 1992:726). The list of the districts (1 Ki 4:7-19) covers the territory outside Judah. There is clear evidence that the action of Solomon was deliberate in the sense that the 12 districts did not follow the old tribal lines. The blatant absence of Judah from the list is a strategy to exempt Judah from the obscene taxation (McKenzie 1992:12). Judah was favoured and injustice was carried out against other tribes.

The construction and dedication of the temple are the centrepiece of the story of Solomon, because the temple remains a continuing area of interest in Kings with cultic deviations or reformations, (1 Ki 14:25-28; 15:15, 18-19, 2 Ki 11:3-16; 12:4-18, etc.) (Walsh \& Begg 2018:16). The temple was the central, symbolic stronghold of the Jews, which glittered with gold and shinning white stone (Goldhill 2004:1). So many religious and political activities of the Jews happen in the temple. It was David who gave the plans for the building of the temple to Solomon.

\section{Immediate context}

After the death of Solomon in 932 BC, his son Rehoboam went to Shechem for his coronation as the successor. Shechem was in the territory of the northern tribes that his late father had enslaved. At Shechem, the northern Israelites led by Jeroboam appealed for social justice and 
fair distribution of power and resources. Rehoboam advised them to come back in 3 days. Rehoboam was made king over all Israel (1 Ki 12:1). Rehoboam's abortive parley with the assembled elders of Israel at Shechem may supply a sort of reverse paradigm (1 Ki 12:1-20). He came to be confirmed king over all Israel (Hauer 1967). After three days, the elders of Israel were told by Rehoboam that he would continue with the injustice that his father had begun. He refused to remove the burden the northern inhabitants asked for, but instead Rehoboam rendered denigrating and repressing words on elders of the northern platform. This was elucidated more in the close reading of the pericope. This left Rehoboam sustained only by his native tribe of Judah and subsequently by the satellite tribe of Benjamin (1 Ki 12:21) (Hauer 1967). Rehoboam met his political disaster at Shechem. His coronation as the king misfired because of his hate speech against (mostly) the people of northern Israel.

\section{A close reading of 1 Kings 12:1-24}

In the light of its literary structure, the researcher agrees with division made by several scholars (Cohn 2010; Frisch 1991; Nelson 2012). The pericope has six parts, viz: verses 1:1-3a (1), verses $3 b-5$ (2), verses 6-11 (3), verses 12-16 (4) verses 17-19 (5) and verses 20-24 (6).

\section{Coronation of Rehoboam as King (vv. 1:1-3a)}

Rehoboam came to Shechem to be coronated in the midst of the people of Israel. It was an assembly of Israelites. According to Heater (1991:123) 'Shechem had religious significance, going back to the patriarchs'. It was a place of ancient traditions in Israel - Jacob came on his return from Haran, Joshua and the enlargement of the Israelite amphictyony (Mauchline 1976:343). The exposition (vv. 1:3) describes a national assembly or a national conference, which was indeed needed at this nascent monarchical period of the Israelites. The Hebrew word ?הָ? which means an assembly, congregation, assemblage of persons (Davidson 1970:655), convocation, a constitutional referendum, is a common noun; its gender is masculine, with the singular form, from the root קהל It indicates that the nation of Israel, not a geographic selection, was present at the coronation of Rehoboam, and in this assembly (קָּ? matters of national importance must be discussed. It was

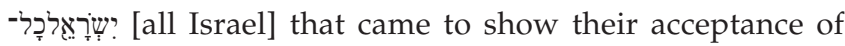
Rehoboam as their King (Kohlenberger 1987:379).

\section{Hate actions (vv. 3b-5)}

The people appealed to Rehoboam to make the yoke that Solomon had placed on them lighter. Precisely, they were people from the northern tribes. They came to Rehoboam because the 'well-being of the people has been tied up with the Kings' (Goldingay 2016:187). In verse 4, there are two sides. In verse $4 a$, there is the use of the word meaning 'your father', indicting Rehoboam in the sins of his father. However, in verse $4 \mathrm{~b}$, the word הָָּּבָ exonerated Rehoboam from sharing in the wickedness of his father, which is only possible if he הקֶָ [lightens] the yoke of Solomon. The yoke was conscripted labour that his father Solomon had placed on them (Ki 11:28) (Hale \& Thorson 2007:632). The Hebrew word הקָל is a verb, from the hiphil pattern; an imperative and a masculine singular in gender and form, respectively. The people had no intention of having a second Solomon that would enforce high taxation, tedious labour, and a horde of administrative minions, instead they demanded relief (Hale \& Thorson 2007:343). The yoke became too ?ִשֶ [hard] because of the maltreatment, which imposed great hardship on the people (Walsh 1995).

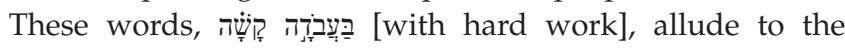
enslavement under Pharaoh in Exodus 1.14; 6, 9 and Deuteronomy 16, 6.24 (Avioz 2005:23; Frisch 1986:99). Barton and Muddiman (eds. 2007:237) explained that this hardship is the cause of the kingdom's partition (1 Ki 12): its partition into northern and southern kingdoms of a onetime united Israel.

\section{Consultations for social justice and fairness (vv. 6-11)}

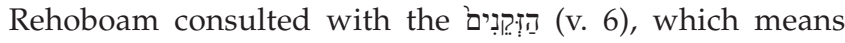
the old men or elders. This was a right step. However, he failed to provide the argument of the people of Israel to the elders (v. 6) in contradiction to his action in verse 9. Verses 6 and 9 contain the motif of the wise against that of the foolish advisors. In verse 8 , Rehoboam provided the people's argument to the הַיְלְדים [young men]. He

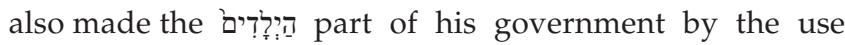

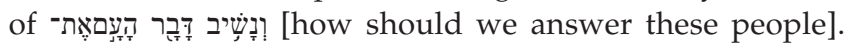
This shows that he had confidence in the advice of his friends than with the elders and those considered to mean well for the society. In verse 6 , he told to elders

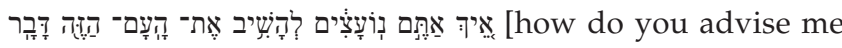
to answer these people a word], authoritatively proving that he is in charge and can do an undo. Rehoboam was disappointed with the counsel of the elders and he turned to the counsel of the youngsters of the royal court in matters of policy (Malamat 1999:37). In verse 6, he uses... advise me to answer this people a word... which shows his lack of accommodation of the views of the elders who may be considered wiser and more experienced in his environment. The old men gave typical sage advice: be a servant 'today'; they will be your servants forever ('all the days'). It shows that the loyalty of a people stems from a king's willingness to act as a public servant. In verse 7, the use of Iְ Ito speak with], which is a verb, class of piel waw consecutive, from the root (Holladay 1988:67), shows that the decision was borne through negotiation.

\section{Hate speech between the ruler and the ruled (vv. 12-16)}

After three days had elapsed, people came to Rehoboam to get a reply. In verse 13, he responded to them in a harsh way

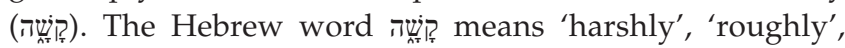
'arrogantly', 'severely' and so on. This was in accordance with the advice of his contemporaries. Gotom (2006) observed that: 
Foolishly, he chose to follow their advice ... the elders advised Rehoboam to be a servant leader to his people, while the young advised him to be a dictator. Rehoboam missed the blessings of wise counsel ... servant leadership is more than just a model that glues the leader to his or her people. It is also a sign to obedience to Jesus, who left his home in glory to become part of humanity (Phlm 2:6-8) and washed his disciples' feet, giving them an example that they should follow (Jn 13:14-15). (p. 432)

Rehoboam forgot to understand that 'God gives authority to kings and leaders so that they may serve others, not themselves' (Hale \& Thorson 2007:632). In verse 14, Rehoboam showed that he knew the actions of his father

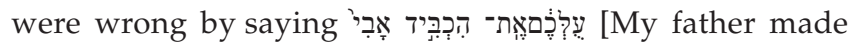
your yoke heavy]. Rehoboam shows that he would follow his father's ways (Kalimi 2018). In verse 14, Rehoboam said that he would not use [whip] as his father did, but he would use עַקָרָב [scorpion]. Smith (1930:789) called this reply an 'arrogant answer'. Hale and Thorson (2007:632) reported that Rehoboams meant by his speech that his 'smallest measures would be harsher than his father's

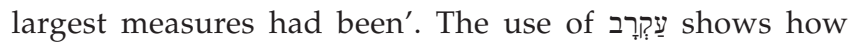
fierce in oppression he would be compared with his father. By using scorpion, it showed how cruel Rehoboam was to the yearnings and aspirations of the people of Israel (Killeen 2010). Rehoboam chooses slogans over wisdom, machismo over servanthood. The 'yoke' (על [ol]) in verse 14 consisted of heavy taxation and demand for labour and military service. The chastening would involve still more oppressive treatment, but probably not with whips or scorpions, literally. Likewise, the 'slaves' in Egypt may not have made all bricks with their own hands (Ex 1:8-14) (Buchanan 1972).

The northern tribes came to the conclusion 'what portion have we in David'. This indicates that the people were resolute in their revolt, because they found that the government is intolerable to their needs (Henry 2006:499). In

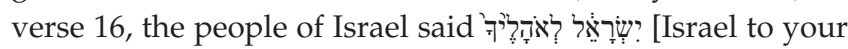
tents], which was a reminiscence of the Egyptian tent life. It is derived from the Hebrew word אהזל, which is a noun masculine, which means a tent, home, dwelling place or an abode. This state was an encouragement to anarchy. It was a clarion call for rebellion against the government of Rehoboam (Friedman \& Friedman 2019). According to Gordon (2012), the tent became a place for self-rule through the practical cooperation by the northern tribes. Its cooperation was practical and theoretical in deeds and words.

\section{The conflict (vv. 17-19)}

Because of the hate speech between Rehoboam and the people of Israel, the kingdom of Israel was dissolved and disintegrated. Rehoboam's heavy-handedness is portrayed as the immediate cause of the break between Israel and Judah (Walsh \& Begg 2018:169). He was unable to realise that the people of northern Israel had resorted to civil disobedience, and he sent Adoram to collect the usual revenue.
Adoram was stoned and he died (v. 18). It showed Rehoboam that the people were earnest about their demands (Mauchline 1976:344). Rehoboam climbed his chariots in לִגִּ [haste] to Jerusalem (See Davidson 2007:438). The Hebrew word לנגוּס means 'to flee', 'take a flight' or 'to escape' and it has the qal pattern and is a verb. This chain of events starts with Jeroboam as the loser who has fled (11:40), but ends with Rehoboam fleeing instead (v. 18). There are two scenes involving Rehoboam and the people enclose Rehoboam's interaction with his advisors (vv. 3b:5 and 12-16). In a structural sense, this folkloristic narrative is a developed story, with exposition (v. 13), complication (vv. 14-15), climax (v. 16) and denouement (vv. 17-20). Gray (1999) wondered that Rehoboam seems to have been incredulous as to the reality of the revolt (v. 18). It may be concluded that the author of this passage was unmistakably a Judean who admitted that Rehoboam played a part in the partition, but who regarded it as a perverse rebellion (v. 19) (eds. Barton \& Muddiman 2007). This means that the writer of Kings, may have been from the lineage of Judah who presented facts showing that the rebellion of the northern house of Israel was to be condemned and named as an unreasonable, illogical and unacceptable conduct against state authority of Rehoboam.

\section{Israel's rebel against Rehoboam (vv. 20-24)}

Jeroboam was made king of Israel. In verse 20, the people

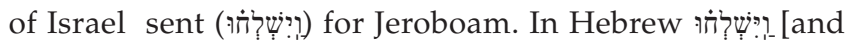
they sent for him] is derived from שָָָׁ, which means sent, stretch and thrust. The people of Israel rejected Rehoboam and his father's house and stretched their hands to Jeroboam. It was only the tribe of Judah that remained with Rehoboam (v. 20). Ten other tribes went with Jeroboam. Rehoboam wanted to use physical violence against Israel with over 180000 people (v. 22), but God

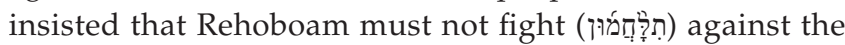
brothers. It shows that the Lord intended for two kingdoms to exist together as brothers under his rule (Gotom

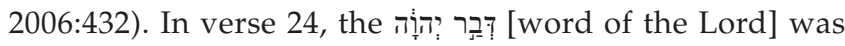
repeated three times to show the severity of God's insistence that Rehoboam must not do anything further to escalate the conflict between the north and the south. It also shows the great significance of God's position on the plight of the northern Israelites (Swaggart 2006:601). The Hebrew word תִ תִ apart from fight also means battle, threaten and devour. God told Shemaiah that

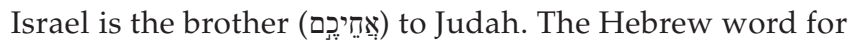
brother אָחזיכָּ could also mean companions, relative, that is, people of alike or of like minds. This shows that Israel and Judah were recognised by God as people of like minds.

Rehoboam was able to rule for just 17 years. In the history of King Rehoboam, the major point is his indiscreet treatment of the tribes at his accession, which resulted in the revolt of the best part of the nation and the establishment of a rival kingdom (Smith 1930:789). 


\section{Understanding hate speech}

A hate speech could be defined as a speech that is tribally, ethnically, socially, religiously and racially offensive. It can also be defined as any speech that is used in a demeaning way to certify and authorise the suppression of a group or persons. Hate speech refers to any speech that subordinates, marginalises or harms members of an oppressed group (Schwartzman 2002:421). This oppressed group is abused economically, socially, religiously and politically. The promoters and orchestrators of hate speech are being motivated and entertained by religion, race, ethnicity, politics, gender and homophobia among others (Nielsen 2002:265). When these motivating factors otherwise known as causative factors are controlled, hate speech becomes a reduced phenomenon. Lederer and Delgado (eds. 1995:5) said that hate speech usually includes physical, verbal, symbolic and other acts, which bring an atmosphere of fear, harassment, low selfesteem, discrimination and intimidation.

Hate speech could be caused by various factors.

\section{Harmful actions}

When those in leadership positions carry out policies and actions that are inimical to the growth and development of a section of the population, it is a hate action. Most of the times, policies are enacted by leaders against people different from their religion, tribe or ethnic group. For instance, in 2016 the military introduced a combat that was suspected to be targeted at indigenes of eastern Nigeria. This combat was known as 'python dance'. It was presumed by people of the region to be a hate action against the easterners. When an anomaly is observed, the victims resort to hate speech online and offline as a way to protest against their victimisation. Isiokpo asks a question: '[w] hat would one say about a Father unleashing military might code named "Operation python dance" against his unarmed civilian population (the children) claiming to go for thieves and kidnappers' (Isiokpo 2017:1).

\section{Political and economic struggle}

There is a high consciousness for the control of political and economic rights and opportunities by persons or groups. Certain persons who feel deprived of some political rights or opportunities, religious freedom, economic rights and opportunities tend to vent their anger in hate speech that shows their discontent with the scheme of things.

Becker, Byers and Jipson (2000:38) called this group of persons 'a historically oppressed group'. This group has a sense of deprivation because of the superiority of other religious and ethnic groups in Nigeria (Agbese 2018). In many cases, people respond to hate speech with hate speech if they are seeking to gain control of a situation or to be recognised.

Unfortunately, it leads to violence; if the ultimate response leads to violence, then both parties (the aggressor and the victim) should feel accountable (Nigeria's Stability and Reconciliation Programme 2017).

\section{Hubris and narcissism}

Leaders in Nigeria exhibit a high level of hubris to show how powerful they are. They intimidate the citizens, trample on their rights, subvert constitutional provision and empower themselves and their cronies to the detriment of citizen's welfare. They exercise the use of derogatory languages for their perceived enemies, not minding the security, social, religious and economic implications of their hate speech or actions. Nigerian leaders hubristically abuse power, damaging the lives of others because of the fact that they are dictators (Owen \& Davidson 2009). This is the reason why other citizens incite violence to vent their anger and frustration.

\section{Offensive public speech in Nigeria}

Hate speech in most countries has led to the death of innocent citizens and destruction of property. It has so many consequences, which may be political, social, economic and political. In Nigeria, hate speech is causing tensions along religious, ethnic and socio-cultural lines. Nigeria is a country made up of so many religions, ethnic groups, tribal groups, political groups and socio-cultural groups. In Nigeria, hate speech is any speech that promotes, celebrates or appreciates hate crimes such as terrorism, maiming and killing of innocent citizens and destruction of lives and property. A person or group must threaten violence, declare it has a violent mission or actually take part in acts of violence (eds. Lederer \& Delgado 1995:5). Table 1 shows hate speech driven by ethno-religious concerns.

\section{Impacts of hate speech in Nigeria}

The impacts of hate speech in Nigeria cannot be overemphasised. They further intensify ethnic tension, ethno-religious disunity and calls for disintegration.

There is an increase in ethnic tension in Nigeria aggravated by hate speech from aggressors (leaders) and victims (dispossessed and depressed citizens). This ethnic tension has gradually metamorphosed into religious tension. According to the 2019 report of the Humanitarian Aid Relief Trust, further religious and territorial tensions were brought about by the Fulani herdsman where attacks have continued, notwithstanding the military claim that insurgency has been technically defeated (Hassan 2019:1). People in Benue, Plateau and Taraba, with predominantly Christian population, have been rendered homeless, living in internally displaced camps and sanctuaries, with the blatant refusal of the government in power to remove the Fulani herdsmen from their lands.

Most ethno-religious crises in Nigeria are the offshoot of hate speech. This is because these speeches were based on tribal-cum-religious sentiments. Some of them include the 
TABLE 1: Hate speech driven by ethno-religious concern in Nigeria.

\begin{tabular}{|c|c|c|c|c|}
\hline S/No & The speaker & The message & Date & Source \\
\hline \multirow[t]{4}{*}{1} & Muhammadu Buhari & $\begin{array}{l}\text { Muslims should vote only for the presidential candidate who would } \\
\text { defend and uphold the tenets of Islam. }\end{array}$ & 20 January 2003 & $\begin{array}{l}\text { https://allafrica.com/ } \\
\text { stories/200201210250.html }\end{array}$ \\
\hline & & $\begin{array}{l}\text { God willing, by } 2015 \text {, something will happen. They either conduct a } \\
\text { free and fair election or they go a very disgraceful way. If what } \\
\text { happened in } 2011 \text { (alleged rigging) should again happen in } 2015 \text {, by } \\
\text { the grace of God, the dog and the baboon would all be soaked in } \\
\text { blood. }\end{array}$ & 14 May 2012 & $\begin{array}{l}\text { https://www.vanguardngr. } \\
\text { com/2012/05/2015-II-be-bloody-if- } \\
\text { buhari/ }\end{array}$ \\
\hline & & $\begin{array}{l}\text { Whilst the Niger Delta were treated like kings, the Jama'atu Ahlis } \\
\text { Sunna Lidda'Awati Wal-Jihad, which some people call Boko Haram, } \\
\text { are being killed and their houses destroyed unlike the special } \\
\text { treatment given to the Niger Delta Militants. This is injustice to } \\
\text { Northern Nigeria. }\end{array}$ & 02 June 2013 & $\begin{array}{l}\text { https://thewillnigeria.com/news/ } \\
\text { opinion-general-muhammadu-buhari- } \\
\text { why-we-cannot-trust-him-with-our- } \\
\text { collective-destiny-in-2015-just-yet/ }\end{array}$ \\
\hline & & $\begin{array}{l}\text { I hope you have a copy of the election results. The constituents, for } \\
\text { example, gave me } 97 \% \text { [of the vote] cannot in all honesty be treated } \\
\text { on some issues with constituencies that gave me } 5 \% \text {. }\end{array}$ & 24 July 2015 & $\begin{array}{l}\text { http://saharareporters. } \\
\text { com } / 2015 / 07 / 25 / \\
\text { buhari\%E2\%80\%99s-statement-us- } \\
\text { institute-peace-made-everyone- } \\
\text { cringe-0 }\end{array}$ \\
\hline 2. & Alhaji Mujahid Dokubo-Asari & $\begin{array}{l}\text { The year } 2015 \text { is more than do-or-die. You are a man and I am a man, } \\
\text { we are going to meet at the battlefield. Muhammadu Buhari of the } \\
\text { All Progressive Congress is a beast clothed in human skin. }\end{array}$ & 02 March 2014 & $\begin{array}{l}\text { https://www.newsexpressngr.com/ } \\
\text { news/5646-Dokubos-message-to- } \\
\text { Boko-Haram-Well-meet-at-the- } \\
\text { battlefield-Says-Jonathans-re-election- } \\
\text { more-than-do-or-die }\end{array}$ \\
\hline 3. & Northern Elders Forum (NEF) & $\begin{array}{l}\text { We'll regard anyone who votes for the People's Democratic Party as } \\
\text { enemies of the North. }\end{array}$ & 14 October 2014 & $\begin{array}{l}\text { https://www.vanguardngr. } \\
\text { com/2014/10/2015-well-regard- } \\
\text { anyone-vote-pdp-enemy-north-nef/ }\end{array}$ \\
\hline 4. & Mrs. Patience Jonathan & $\begin{array}{l}\text { Our people no dey born shildren wey dem no dey fit count. Our men } \\
\text { no dey born shildren throway for street. We no dey like the people } \\
\text { for that side (Almajiri). }\end{array}$ & 02 March 2015 & $\begin{array}{l}\text { https://www.legit.ng/405585-patience- } \\
\text { jonathan-wrongly-criticized-for- } \\
\text { throwaway-children-comment.html }\end{array}$ \\
\hline 5. & Oba Akiolu of Lagos & $\begin{array}{l}\text { On Saturday, if anyone of you, I swear in the name of God, goes } \\
\text { against my wish that Ambode will be the next governor of Lagos } \\
\text { state, the person is going to die inside this water... For the Igbos and } \\
\text { others in Lagos, they should go where the Oba of Lagos heads to. }\end{array}$ & 03 April 2015 & $\begin{array}{l}\text { http://dailypost.ng/2015/04/06/ } \\
\text { anyone-that-does-not-vote-ambode- } \\
\text { will-be-thrown-into-lagoon-oba-of- } \\
\text { lagos-warns-igbos/ }\end{array}$ \\
\hline 6. & Tele Ikuru & $\begin{array}{l}\text { It is necessary for the sake of your fathers, for the sake of your } \\
\text { mothers, for the sake of your brothers and sisters and for the sake of } \\
\text { your children. Every Rivers man must stand up to fight this evil among } \\
\text { us. If it demands your blood, so be it. }\end{array}$ & 20 April 2015 & $\begin{array}{l}\text { http://saharareporters. } \\
\text { com/2015/04/20/us-likely-sanction- } \\
\text { patience-jonathan-orubebe-others- } \\
\text { over-election-incitement-rigging }\end{array}$ \\
\hline 7. & AREWA & $\begin{array}{l}\text { It has been ceased to be comfortable or safe to continue sharing the } \\
\text { same country with the ungrateful, uncultured lgbos who have exhibited } \\
\text { reckless disrespect for the other federating units and stained the integrity } \\
\text { of the entire nation with their insatiable criminal obsessions. }\end{array}$ & 06 June 2017 & $\begin{array}{l}\text { http://saharareporters. } \\
\text { com/2017/06/06/northern-youths- } \\
\text { declare-war-igbos-north-ask-them- } \\
\% \text { E2 } \% 80 \% 98 \text { leave } \% \text { E2 } \% 80 \% 99 \text { - } \\
\text { within-three-months }\end{array}$ \\
\hline 9. & Armed hoodlums & $\begin{array}{l}\text { Igbo should go back to their States to do business. This is Lagos. We } \\
\text { campaign for them to vote for Buhari, but they refused and voted for } \\
\text { Atiku. They cannot come here to do business again. They must follow } \\
\text { us to vote whoever we ask them to vote for. This is just a sample for } \\
\text { them, if they ever vote for the People's Democratic Party again, that } \\
\text { will be their end. }\end{array}$ & 27 February 2019 & $\begin{array}{l}\text { https://www.pmnewsnigeria. } \\
\text { com/2019/02/27/hoodlums-attack- } \\
\text { igbo-traders-on-lagos-island-for- } \\
\text { failure-to-vote-for-buhari/ }\end{array}$ \\
\hline
\end{tabular}

Ilorin religious conflict of 1986, the Bauchi crises of 1992, the Kaduna crises of 2000, the Jos crises of 2001 and the Benue crises of 2018. The lives that have been lost because of this wanton destruction are innumerable. The properties that have been lost are worth trillions of naira. Life is considered as a fathom that can be taken at will. Unfortunately, people use this type of deep-seated animosity in their speech precisely because of the culture of impunity, which reigns in Nigeria. When these conflicts break out people are slaughtered and no one is punished (Snaddon 2019:1).

There have been several calls for the disintegration of Nigeria because of hate speech from leaders. Several states, regions or even groups are clamouring for self-governance because of the various hate speech emanating from the leaders and the ruled (Hassan 2019:1). For instance, the Afenifere of western Nigeria and the Ohanaeze Ndigbo of eastern Nigeria have been calling for the restructuring of Nigeria or its disintegration.

During the time of Goodluck Jonathan, the northerners were calling for the disintegration of Nigeria because of the perceived inequality in the distribution of political positions and human and material resources. During the time of
Buhari, the easterners are calling for the disintegration of Nigeria because of the hate speeches and the perception of political, economic and social fairness to the region. Sadly, politicians thrive on the manipulation of ethnicities and religions. This has worsened the politics of identity (This Day 2017). The politics of identity covers identifying policies with particular groups, regions or religions.

Economically, the country is experiencing turbulence. Hate speech from the leader and the led hurts the economy and has succeeded in rubbishing the current economy of Nigeria (Ojoye 2017) and also scaring investors about bringing their resources into Nigeria. The effect of harsh labour on a segment of Nigerians cannot be underestimated. For instance, poverty is on the increase in the south-eastern Nigeria. Business people in south-eastern Nigeria are made to import their goods from Lagos, which is very far from the region. The south-eastern region is the business hub of Nigeria yet there is no seaport in the region. This has made life very harsh and hard for the people. For instance, prices of goods are high in the south-east because of distance which makes cost of transportation high. The government of Nigeria said that Igbo land is landlocked. Ejimakor (2020:1) revealed that a false 
statement has been institutionally purveyed since the end of the Civil War. This is the falsehood that Igbo land is landlocked or has no access to the sea. Furthermore, the Igbo ethnic group has not been in a sensitive position in Nigeria, which is the reason for the increasing poverty and helplessness of the region. Furthermore, there is no development from the federal government in south-eastern Nigeria. Mr Njoku lamented that Nigerian government is maltreating the Igbo people like slaves (BBC 2017:1).

Also, there are harmful actions against a segment of the Nigerian population. There is scarcity of goods and increase in prices of goods because of the blockade of land borders in southern Nigeria. There is harsh economy in the south whilst the northern part of Nigeria has her borders open and there is the inflow of goods and services. The citizens of the south see this as a ploy by the government to favour the north against the south. In fact, on 29 May 2021, at Idiroko, Ipokia Local Government Area of Ogun State, Southern Nigeria some Yoruba nation agitators stormed the area and forcefully opened its land border. They accuse the Federal Government of Nigeria of shutting down the land borders in the South, which has caused untold hardship and harsh labour to the people of southern Nigeria whilst those in the North were open (Olatunji 2021:1). Furthermore, it may increase attacks or resume attacks on oil facilities all over the Niger Delta (southern Nigeria), thereby reducing the nation's daily output and income. The people of the oil producing regions of the south feel that they are been jilted and cheated by the northern controlled federal government. The perceived conflict is because of the lack of adequate justice and human rights abuse of the people of the Niger Delta, southern Nigeria (Umar \& Othman 2007:6).

\section{Kings 12:1-24 and the Nigerian situation}

Leaders are voted by the people. During their inauguration, the people roll out drums to support their leaders. The people of Israel trooped en masse to inaugurate their leader Rehoboam. The purpose of the summit was a coronation, although it still requires popular assent of the people gathered to make Rehoboam king (Beentjes 2011:164). This assent shows that the people wholeheartedly agreed to the choice of their leader. The people representatives made up the assembly, which was the supreme authoritative and legal body chiefly during the pre-monarchic period. It was empowered both to elect kings (as in the case of Jeroboam) and to reject would-be rulers (as was done with Rehoboam) (Malamat 1965). This is similar to the situation in Nigeria. Leaders are, as much as possible, elected by everybody. The votes of the people show their acceptance and during their inauguration an assembly gathers to coronate the leader. In Nigeria, leadership works well enough as long as the masses agree to support their leaders (ed. Roberts 2015). Furthermore, electoral participation or a lack thereof may be one of the greatest relevance for the health and legitimacy of governments and it can affect government in many ways (Simonsen \& Robbins 2018). Nigerian citizens are principals who chose representatives to serve as their agents in government (Lupia \& McCubbins 2000:291).

National Confab as a national assembly has been organised by succeeding governments. For instance, on 07 March 2014, President Goodluck Jonathan organised a national conference and it was headed by Idris Legbo Kutigi, a retired chief justice. Part of the objectives of the conference includes politics and governance, human rights and legal reform, social welfare, religion and development. Fortunately, National Confab Report published in 2014 recommended a regular introduction, implementation and stabilisation of avenues to strengthen the faith of the citizenry in the amended constitution and the federation in a bid to address the issues that centre around restructuring or renegotiating the entity called Nigeria, with more powers to the constituent units of the federation (Editorial Board 2017:1). It was an avenue to calm down the tension in the highly religious polarised entity such as Nigeria. In the case of Rehoboam, he consulted two separate bodies of advisors, with the bad advisors challenging him to continue in his odd ways (1 Ki 12:8-12) (Halpern 1974:527). The two bodies were to provide solutions to the lingering crises in Israel.

The Nigerian government has neglected recommendation of the national conference report. These conferences include the 1995, 2005 and 2014 national conferences. The reports of the conferences recommended strategies that will help in the unity, growth and development of Nigeria. Unfortunately, the report was swept under the carpet, leading to a duplication of tribalistic and religiously orchestrated decisions and appointments by succeeding governments in Nigeria. There have also been gross violations of human rights in Nigeria. This is similar to the situation of Rehoboam's reign. He abandoned the prayer of the people and chose to be partial in governance. Rehoboam was so insensitive on the issue of social welfare and social justice for all Israel that representatives of the Northern tribes asked him to reduce his impositions (Klein 1982:285). Rehoboam could not identify his capacities or strengths and failed to analyse whether he was neglecting, misusing or making partial use of them (Marshall 2003). He used several hate statements such as 'adding to their yoke', 'chastening them with scorpions' and 'making his finger thicker than his father's loins'. Rehoboam exhibited pride, hubris and narcissism. He underrated the powers and privileges of the citizens. He has the inordinate and unreasonable self-esteem, which made him arbitrary in power (Mant 1837:51). In Nigeria, leaders made provocative, dangerous and hate speeches. These hate speeches cut across ethnic and religious lines. Political and religious leaders make counter-speeches, which are inflammatory. During campaigns, presentations and symposiums, leaders make hate speech that deteriorates the already fragile peace and unity in Nigeria. Uzuakpundu lamented that it has culminated in unnecessary tension that is affecting national peace, security and harmony (Uzuakpundu 2019:1). 
The participation of citizens in cases of hate speech has further aggravated the hate among ethnic poles in Nigeria. Citizens, in order to show their displeasure with the government in power, resort to making of allegations and counter-allegations that are very unhealthy to Nigeria's health in the development space. Citizens generally often harbour ill feelings towards their government when they reckon that they are being cheated or mistreated (Onyibe 2019). This is the reason that hateful and defamatory speech would be exceedingly difficult to eradicate (Benesch 2014). This is similar to the situation of the Israelites when they said 'to your tent, O Israel'; it was a call to 'anarchy' (Oye 1985). Anarchy in the sense that anyone is free to do whatsoever thing he finds pleasing to do. Anarchy as an action impedes the achievement of international cooperation, which is mainly because of the absence and efficiency in the running of government. Because of the fact that Rehoboam exceeded the bounds of injustice, nepotism and partiality, the northern Israelites resorted to civil disobedience (Kavanagh \& Oberdiek 2013). Different ethnic and religious groups have resorted to anarchy in Nigeria. The striking slogan 'To your tents, O Israel' is no more than a formula signifying dissolving an assembly or its disbandment with the emphatic supplement 'what portion have we in David?'; it was instead an outright nullification of the treaty with the David's house (Fohrer 1959 in Malamat 1965:39).

There was the use of key words such as portion, tents and inheritance. According to Malamat (1965), they may well date back to the period of Israelite settlement, the formula having its roots in the tribal assembly and organisation. This reveals a clarion call for restructuring of Israel or, better say, the disintegration of a united Israel.

Unfortunately, instead of Rehoboam findings ways of deescalating the conflict, he resorted to gathering over 180000 soldiers to fight northern Israel that felt oppressed. Nigerian leaders tend to be oppressing regions they are not from. For instance, from 2015 to 2021, all the top positions in Nigerian government are occupied by people from northern Nigeria. The southerners see this as injustice and feel that their plights are not considered by the government controlled by people from the north.

\section{Suggestions}

The following recommendations would serve as proposal towards addressing the challenges of hate speech in Nigeria:

- Unlike Rehoboam, leaders should not continue in verbal, symbolic and other acts that bring an atmosphere of fear, harassment, low self-esteem, discrimination and intimidation of any section of their people they are ruling. This may lead to insubordination and conflict escalation.

- Just like Israel, the populace should first bring their fears and plights to the leaders rather than resorting to arms and acts that may not be healthy to the oppressed and the oppressor.

- The government of Nigeria should learn not to provoke the citizens through their harmful actions and speeches just like Rehoboam, which may be in the form of nepotism, partiality and social injustice.

- Nigerian leaders should listen to the voices of their electorate (people), rather than exhibiting leadership hubris and narcissism, which will make the country uncomfortable both for the ruled and the ruler.

- Lack of self-control by Rehoboam escalated the already fragile unity in Israel. Thus, rather than resorting to hate speech as a way of venting their frustration at the request of citizens of a particular region for egalitarianism and good governance, Nigerian leaders should engage the citizens through dialogue.

- Political and religious leaders should be careful with their words and language and avoid hate speech that may be injurious to national health and development.

- Leaders should be careful of those they include as part of their kitchen cabinets. Rehoboam had bad advisers in his cabinet. Bad advisers bring about bad governance.

- Citizens should be careful about how to react to certain government policies. They should be calm when the call to rebel emanates from a person or a group. This is because (a) person(s) or group(s) can decide to cause anarchy and violence in any society from which they gain nothing.

- Nigeria is bigger than any individual or group. In order to promote justice, equity and fairness, all regions should be given their proper place politically, economically, physically, socially and otherwise.

\section{Conclusion}

Rehoboam's use of harsh words on his people instead of kind words made them afraid and not loyal to him and it led to the collapse of a united Israel, thus it opened room for invaders. The hate speech from the people of Israel to their ruler served as a counter-speech to the provocative statement of Rehoboam; however, the short- and long-term implications were devastating. They lost touch with their brethren, Benjamin and Judah. They were attacked by their enemies and were never restored as a kingdom. Nigeria as a nation cannot afford to witness another civil war. It is high time that the different regions and religious groups meet to find a lasting solution to the perceived oppression, segregation and dehumanisation from hate speech emanating from rulers and from the citizens. This will, in the long run, provide an avenue to the aggrieved citizens to air their views. Furthermore, the views of the people should not be taken with a pinch of salt. Leaders should try as much as possible not to impose their wishes and aspirations on the people. A good leader is a good listener and a good servant.

\section{Acknowledgements Competing interests}

The authors declare that they have no financial or personal relationships that may have inappropriately influenced them in writing this article. 


\section{Authors' contributions}

F.C.U. and M.J.O. contributed equally to the writing of this article.

\section{Ethical considerations}

This article followed all ethical standards for research without direct contact with human or animal subjects.

\section{Funding information}

This research received no specific grant from any funding agency in the public, commercial or not-for-profit sectors.

\section{Data availability}

Data sharing is not applicable to this article as no new data were created or analysed in this study.

\section{Disclaimer}

The views and opinions expressed in this article are those of the authors and do not necessarily reflect the official policy or position of any affiliated agency of the authors.

\section{References}

Agbese, D., 2018, 'Hate speech', The Vanguard, December 19, p. 1.

Alechenu, J., Baiyewu, L. \& Aluko, O., 2018, 'Death for hate speech: CDHR, others kick as Senator defends', The Punch, 04 March, p. 1.

Avioz, M., 2005, 'The characterization of Solomon in Solomon's prayer (1 Kings 8)', Biblische Notizen 126, 23.

Barton, J. \& Muddiman, J. (eds.), 2007, The Oxford Bible commentary, pp. 237-241, Oxford University Press, Oxford.

BBC, 2017, 'Nigeria treats us like slaves' - But is Biafra the answer?, viewed 06 July 2017, from https://www.bbc.com/news/world-africa-40506251.

Becker, P.J., Byers, B. \& Jipson, A., 2000, 'The contentious American debate: The first amendment and Internet-based hate speech', International Review of Law, Computers \& Technology 14(1), 38. https://doi.org/10.1080/13600860054872

Beentjes, P.C., 2011, Rewriting biblical history: Essays on Chronicles and Ben Sira in honor of Pancratius C. Beentjes, Walter de Gruyter, Berlin

Benesch, S., 2014, Countering dangerous speech: New ideas for genocide prevention, p. 12, US Holocaust Memorial Museum, Washington, DC.

Buchanan, G.W., 1972, The Anchor Bible, to the Hebrews, p. 69, DoubleDay, New York, NY.

Cohn, R.L., 2010, 'Characterization in Kings', in The Books of Kings, pp. 89-105, Brill, New York, NY.

Cortese, A.J.P., 2006, Opposing hate speech, p. 77, Greenwood Publishing Group, Westport, CT.

Davidson, B., 1970, The analytical Hebrew and Chaldee Lexicon, Zondervan, Grand Rapids, MI.

Davidson, T., Warmsley, D., Macy, M. \& Weber, I., 2017, 'Automated hate speech detection and the problem of offensive language', in eleventh International AAA conference on web and social media, p. 512, viewed 12 February 2019, from https://www.aaai.org/ocs/index.php/icwsm/icwsm17/paper/view/15665/14843.

Edeh, S., 2014, 'We'll regard anyone that vote for PDP as enemy of North - NEF', Vanguard, 14 October, p. 1.

Editorial Board, 2017, 'The senate and national confab report', The Guardian, July 03, p. 1. Ejimakor, A., 2020, 'Igboland is not landlocked', The Guardian, May 26, p. 1.

Fohrer, G., 1959, 'Zeitschrift fiir die alttestamentliche Wvissenschaft, LXXI, p. 8, in A. Malamat (ed.), Organs of Statecraft in the Israelite Monarchy', The Biblical Archaeologist 28(2), 39. https://doi.org/10.2307/3211054

Friedman, H.H. \& Friedman, L.W., 2019, 'What went wrong? Lessons in leadership from Solomon, the Bible's wisest and worst ruler', The Journal of Values-Based Leadership 12(1), 9. https://doi.org/10.22543/0733.121.1237

Frisch, A., 1986, 'The narrative of Solomon's reign in the book of Kings', PhD dissertation, Bar-llan University.

Frisch, A., 1991, 'Structure and its significance: The narrative of Solomon's reign (1 Kings 1-12.24)', Journal for the Study of the Old Testament 16(51), 3-14. https://doi.org/10.1177/030908929101605101
Godwin, A.C., 2015, 'Anyone that does not vote Ambode will be thrown into lagoon Oba of Lagos warns Igbos', DailyPost, 06 April, p. 1.

Goldhill, S., 2004. The temple of Jerusalem, Vol. 4, Profile Books limited, London.

Goldingay, J., 2016, An introduction of the Old Testament: Exploring text, approaches and issues, Inter-Varsity Press, Downers Grove, IL.

Gordon, U., 2012, 'Israel's "tent protests": The chilling effect of nationalism', Social Movement Studies 11(3-4), 349. https://doi.org/10.1080/14742837.20 12.708832

Gotom, M., 2006, '1-2 Kings', in T. Adeyemo (ed.), Africa Bible commentary: A onevolume commentary, pp. 407-432, Word Alive Publishers, Nairobi.

Gray, J., 1970, I and II Kings, pp. 243-249, 2nd edn., OTL, Westminster Press, Philadelphia, PA.

Gray, J., 1999, Concise Bible commentary, p. 386, AGES Software, Albany, NY.

Groody, D.G., 2009, 'Crossing the divide: Foundations of a theology of migration and refugees', Theological Studies 70(3), 640. https://doi.org/10.1177/004056 390907000306

Hale, T. \& Thorson, S., 2007, The applied Old Testament commentary, David. C. Cook, Colorado Springs, CO.

Halpern, B., 1974, 'Sectionalism and the Schism', Journal of Biblical Literature 93, (4), 527.

Hassan, C.J., 2019, Humanitarian aid relief trust, ethnic and religious tensions in Nigeria, viewed 05 January 2019, from https://reliefweb.int/report/nigeria/ ethnic-and-religious-tensions-nigeria-update-canon-hassan-john.

Hauer, C.E., 1967, 'Does I Samuel 9:1-11, 15 reflect the extension of Saul's dominions?', Journal of Biblical Literature 86(3), 309. https://doi.org/10.2307/3263011

Heater, H., 1991, 'A theology of Samuel and Kings', in A biblical theology of the Old Testament, pp.123-151, Moody Press, Chicago, IL.

Henry, M., 2006, Matthew Henry's commentary on the whole bible, Henrdrickson Publishers, Inc., Peabody, MA

Holladay, W.L., 1988, A concise Hebrew and Aramaic Lexicon of the Old Testament based upon the Lexical work of Ludwig Koehler and Walter Baumgartner, p. 67, E.J. Brill, Grand Rapids, MI.

Houston, W.J., 2018, 'Corvée in the Kingdom of Israel: Israelites, "Canaanites," and cultural memory', Journal for the Study of the Old Testament 43(1), 30. https:// doi.org/10.1177/0309089215692183

Isiokpo, C., 2017, 'No more hate speeches but hate actions?', The Vanguard, October 16, p. 1.

Kalimi, I., 2018, Writing and rewriting the story of Solomon in ancient Israel, p. 90, Cambridge University Press, Cambridge.

Kavanagh, A. \& Oberdiek, J., 2013, Arguing about law, p. 247, Routledge, Abingdon.

Killeen, K., 2010, 'Chastising with scorpions: Reading the Old Testament in early modern England', Huntington Library Quarterly 73(3), 501. https://doi. org/10.1525/hlq.2010.73.3.491

Klein, R.W., 1982, 'Liberated leadership: Masters and "Lords" in biblical perspective', Currents in Theology and Mission 9(5), 285.

Kohlenberger, J.R., 1987, The interlinear NIV Hebrew-English Old Testament, Zonderan Publishing House, Grand Rapids, MI.

Lederer, L. \& Delgado, R. (eds.), 1995, The price we pay: The case against racist speech, hate propaganda, and pornography, p. 5, Hill and Wang, New York, NY.

Lupia, A. \& McCubbins, M.D., 2000, 'Representation or abdication? How citizens use institutions to help delegation succeed', European Journal of Political Research 37(3), 291. https://doi.org/10.1023/A:1007068904236

Malamat, A., 1963, 'Aspects of the foreign policies of David and Solomon', Journal of Near Eastern Studies 22(1), 8-9. https://doi.org/10.1086/371706

Malamat, A., 1965, 'Organs of statecraft in the Israelite monarchy', The Biblical Archaeologist 28(2), 39-40. https://doi.org/10.2307/3211054

Malamat, A, 1999, 'Naamah, the Ammonite princess, King Solomon's wife', Revue biblique 106(1), 37.

Mant, B.P., 1837, 'Pride, and its effects', The Saturday Magazine 10(296), 51.

Marshall, T., 2003, Understanding leadership, Baker Books, Grand Rapids, MI.

Mauchline, J., 1976, '1 and II Kings', in M. Black \& H.H. Rowley (eds.), Peake's commentary on the Bible, pp. 343-344, Thomas Nelson and Sons, Nairobi.

McKenzie, J.L., 1992, Dictionary of the Bible, p. 828, Geoffrey Chapman, London.

Montgomery, J.A., 1950, The Book of Kings, p. 210, ICC, T. \& T. Clark, Edinburgh.

Nelson, R.D., 2012, First and second Kings, Westminster John Knox Press, Westminster.

Nielsen, L.B., 2002, 'Subtle, pervasive, harmful: Racist and sexist remarks in public as hate speech', Journal of Social Issues 58(2), 265. https://doi.org/10.1111/15404560.00260

Nigeria's Stability and Reconciliation Programme, 2017, How to guide mitigating dangerous speech monitoring and countering dangerous speech to reduce violence, viewed 21 February 2019 , from http://www.nsrp-nigeria redwpcontent/uploads/2017/12/NSRP-How-to-Guide-Mitigating-Hate-and-Dangerouscontent/uplo

Obiorah, M.J., 2015, Bibliotheca Divina: A basic introduction to the study of the Bible, p. 96, University of Nigeria Press, Nsukka.

Ojoye, T., 2017, 'Hate speech is bad for the economy', The Punch, August 23, p. 1

Olatunji, D., 2021, 'Yoruba nation agitators forcefully reopen Idiroko border', The Punch, 30 May, p. 1. 
Onyibe, M., 2019, Mr President, there must be better ways to curb hate speeches, September 15, viewed 12 February 2019, from https://www.thecable.ng/mrSeptember 15, viewed 12 February 2019 , from https://ww
president-there-must-be-better-ways-to-curb-hate-speeches.

Owen, D. \& Davidson, J., 2009, 'Hubris syndrome: An acquired personality disorder? A study of US Presidents and UK Prime Ministers over the last 100 years', Brain 132(5), 1396-1397. https://doi.org/10.1093/brain/awp008

Oye, K.A., 1985, 'Explaining cooperation under anarchy: Hypotheses and strategies', World Politics 38(1), 1-24. https://doi.org/10.2307/2010349

Parker, K.I., 1992, 'Solomon as philosopher king? The nexus of law and wisdom in 1 Kings 1-11', Journal for the Study of the Old Testament 17(53), 84. https://doi. org/10.1177/030908929201705305

Roberts, N.C. (ed.), 2015, The age of direct citizen participation, p. 10, Routledge, Abingdon.

Schwartzman, L.H., 2002, 'Hate speech, illocution, and social context: A critique of Judith Butler', Journal of Social Philosophy 33(3), 421. https://doi. org/10.1111/0047-2786.00151

Simonsen, W. \& Robbins, M.D., 2018, Citizen participation in resource allocation p. XVI, Routledge, New York, NY.

Smith, H.P., 1930, 'Rehoboam', in J. Hastlings \& J.A. Selbie (eds.), Dictionary of the Bible, pp. 789-790, Charles Scribner's Sons, New York, NY.
Snaddon, B., 2019, Hate speech and inter-ethnic violence in Nigeria, viewed 12 December 2019, from https://freespeechdebate.com/discuss/hate-speech-andinter-ethnic-violence-in-nigeria/.

Swaggart, J., 2006, The expositor's study Bible, Jimmy Swaggart Ministries, Baton Rouge, LA.

Sweeney, M.A., 2012, I \& II Kings: A commentary, p. 168, Presbyterian Publishing Corp, Louisville, KY.

This Day, 2017, The virus of hate speech, viewed 02 March 2019, from https://www. thisdaylive.com/index.php/2017/02/15/the-virus-of-hate-speech/.

Umar, A. \& Othman, M.S., 2017, 'Causes and consequences of crude oil pipeline vandalism in the Niger delta region of Nigeria: A confirmatory factor analysis approach' Cogent Economics \& Finance 5(1), 1-23. https://doi.org/10.1080/2332 2039.2017.1353199

Uzuakpundu, N., 2019, 'Elections: Save Nigeria from hate speech', The Guardian, 07 December, p. 1.

Walsh, J.T., 1995, 'The characterization of Solomon in First Kings 1-5', Catholic Biblical Quarterly 57, 489-490.

Walsh, J.T. \& Begg, C.T., 2018, '1-2 Kings', in R.E. Brown, J.A. Fitzmyer \& R.E. Murphy (eds.), The new Jerome biblical commentary, pp. 161-169, Theological Publications, Bangalore. 